DOI: https://doi.org/10.32839/2304-5809/2019-5-69-60

UDC 621.311

Samoilyk Oleksandr, Kurbaka Halyna

Cherkasy State Technological University

\title{
OPTIMIZATION OF MEANS OF DISTRIBUTED GENERATION IN THE STRUCTURE OF LOCAL ELECTROTECHNICAL COMPLEXES
}

Summary. The problem of optimization of distributed generation parameters at the stage of design of the power supply system (PSS) for heterogeneous problems of different degree of complexity and multiplicity of the set goals is considered. The technique of parametric optimization of PSS with DG, which lies in the definition of physically substantiated characteristics of power units and consists of three stages: formation of initial data; determination of the maximum power of a power unit; direct selection (optimization), is developed. The proposed formation of initial parametric base, as well as the use of flexible criteria for options selection allows dynamic adjustment of the task and application both for the design of objects under construction and for the modernization of existing systems.

Keywords: distributed generation, model, optimization, electric load diagrams, power unit.

Самойлик О.В., Курбака Г.В.

Черкаський державний технологічний університет

\section{ОПТИМІЗАЦІЯ ЗАСОБІВ РОЗПОДІЛЕНОЇ ГЕНЕРАЦІЇ У СКЛАДІ ЛОКАЛЬНИХ ЕЛЕКТРОТЕХНІЧНИХ КОМПЛЕКСІВ}

\begin{abstract}
Анотація. Впровадження розподільної генерації (РГ) на стороні споживачів електроенергії у складі електротехнічного комплексу (ЕТК) має ряд позитивних ефектів, але для досягнення максимальних показників ефективності підключення локального джерела живлення потрібне рішення комплексної оптимізаційної задачі, що враховуе як установлювальні параметри енергоблоків (вихідні дані), так і цільові показники і обмеження системи електропостачання (СЕП). Аналіз науко-технічних джерел показав, що більшість сучасних досліджень пов'язані з оптимізацією таких параметрів РГ, як: довгострокове планування розвитку; зменшення втрат при передачі і розподілі електроенергії шляхом раціональної локалізації; ращіональне планування розміщення генерації у вузлах енергосистеми; підвищення стійкості, збереження і поліпшення параметрів якості електроенергії. Такий підхід застосовуеться, як правило, при розгляді оптимізації з точки зору зовнішніх розподільних мережних компаній. Разом 3 тим, практично відсутній науково обгрунтований підхід до визначення фрізично обгрунтованих характеристик енергоблоків у складі електротехнічного комплексу з розподіленою генерацією. У статті розглянуто проблему оптимізації параметрів розподіленої генерації на етапі проектування системи електропостачання для неоднорідних задач різного ступеня складності і комплексності поставлених цілей. Розроблено методику параметричної оптимізації СЕП з РГ, яка полягає у визначенні фрізично обгрунтованих характеристик енергоблоків і складається з трьох етапів: формування вихідних даних; визначення граничних потужностей енергоблоку; безпосередній відбір (оптимізація). Запропоноване формування вихідної параметричної бази, а також використання гнучких критеріїв підбору варіантів допускає динамічне настроювання завдання і застосування як для проектування об'єктів, що будуються, так і для модернізації існуючих систем. На основі залежностей, що характеризують вплив параметрів і структури електротехнічних комплексів з розподіленими джерелами енергії на показники режиму роботи розподільної мережі, представлена цільова функція оптимізації цих параметрів і структури.
\end{abstract}

Ключові слова: розподілена генерація, модель, оптимізація, графіки електричних навантажень, енергоблок.

Tntroduction. Implementation of distributed 1 generation (DG) on the side of power consumers in electrotechnical complex (ETC) has a number of positive effects described earlier, for example, in works [1-4]. In order to achieve the maximum indices of the efficiency of connecting a local power source, a solution of complex optimization task, which takes into account both the adjusting parameters of the power unit (initial data) and the targets and limits of the power supply system (PSS), is required.

Analysis of recent researches and publications. The problem of the study of DG and PSS mutual influence is considered in a number of scientific works. The authors [1] have proposed measures to prevent possible negative effect on the modes of power networks of DG means placed in them. In [2], the method of formation of a prospective plan for the development of power networks with a step-bystep definition of optimal places of DG connection is proposed. In [3], the rise of DG efficiency due to the use of storage batteries is considered. In [4], the peculiarities of the use of cogeneration units, the placement and application strategy of which should be solved taking into account the possibility of efficient use of both thermal and electric power simultaneously, as distributed generation sources are studied. As the criteria for the optimal choice of independent generating units, cost and reliability indices are taken. For parallel operation with power system, the advantages of DG use for compensation of peak loads in terms of economic efficiency and increase of installation readiness coefficient are considered. The comparison of options for independent power supply and parallel DG operation with the network has shown the advantage of the second option in terms of payback: the application of such a concept can improve PSS reliability with less investment and early recoupment, while the above 
facts also have a positive effect on operating costs, including smaller wear and tear of equipment.

Previously unsettled problem constituent. The analysis of works [1-4] has shown that most studies are related to the optimization of the following DG parameters: long-term development planning; reduction of losses in the transmission and distribution of electric power through rational localization; rational planning of the location of generation in power system nodes; increase of stability, preservation and improvement of parameters of electric power quality. Such approach is used, as a rule, when considering optimization from the point of view of external distributive network companies.

At the same time, there is no scientifically grounded approach to the definition of physically substantiated characteristics of power units in electrotechnical complex with distributed generation.

In future, we will be guided by the concept of "internal" approach to DG implementation in consumer power economy. Thus, the processes and parameters that are observed in the system of internal power supply to consumers will be a starting point for constructing the decision principles.

The aim of the article. To develop a technique of parametric optimization of means of distributed generation in the structure of local electrotechnical complexes.

Results. The main task of developing algorithms for DG parameters optimization at the stage of system design consists in the possibility of its practical implementation for heterogeneous problems of different degree of complexity and multiplicity of the set goals. In this regard, it is proposed to structure the technique in stages, each of which can be adapted to the conditions of a specific task.

When constructing the technique, we divide the solution algorithm into three stages: formation of initial data; determination of the maximum power of a power unit; direct selection (optimization).

The first stage is aimed at collecting primary information about the object of research and technological capabilities of the task, thus, it forms the pre-project stage of the work. Then an immediate solution of the problem, intentionally divided into three successive stages, occurs. Considering DG optimization as a complex process, it is advisable to allocate algorithms for structural and parametric optimization in separate stages.

Parametric optimization is to determine nominal parameters of system elements. The purpose of parametric optimization in our task will consist in the determination of physically substantiated characteristics of power units, which is related to solving the tasks of the possibility and feasibility of the planned options implementation. Structural optimization is directed, on the one hand, to the choice of the optimal topology and mode of systems operation, on the other - to the achievement of the maximum technical and economic effect.

Next, we describe the optimization algorithm in stages.

Stage I - Formation of primary initial data. The first step is to record the initial database for optimization of power unit and load parameters. From a mathematical point of view, matrices are a convenient form of writing for further solution. On the basis of initial data processing, design performanc- es, which are further used at the following stages (both for conditional selection and for calculation of optimization criteria), are calculated.

I-I Arrays of load parameters are determined by consumer power consumption in the maximum and minimum state (for example, for operation days) and in general are written as follows:

$$
\mathbf{M P}_{\min / \max }=\left[\begin{array}{ccc}
P_{1} & \ldots & P_{t} \\
Q_{1} & \ldots & Q_{t} \\
S_{1} & \ldots & S_{t} \\
\cos \varphi_{1} & \ldots & \cos \varphi_{t}
\end{array}\right],
$$

where $\mathrm{t}-\mathrm{a}$ number of averaging periods.

Each column of the matrix displays the parameters of power supply modes during the averaging period, thus consumer load diagrams are described. On the basis of further calculation of graph characteristics, an MC matrix, in the rows of which the results in the form of coefficients and quantities characterizing the graphs of active and reactive loading $\mathrm{P}, \mathrm{Q}$ are recorded, is formed.

$\mathbf{M C}_{\min / \max }=\left[\begin{array}{ccccc}K_{\max . P} & K_{\text {f.d.P }} & K_{\text {c.d. } P} & P_{R M C P} & \cdots \\ K_{\max . Q} & K_{\text {f.d. } Q} & K_{\text {c.d. } Q} & P_{R M C Q} & \ldots\end{array}\right]$,

where $K_{\max . P}\left(K_{\max . Q}\right)$ - factor of active (reactive) maximum load;

$K_{\mathrm{f} \text { d.P }}\left(K_{\mathrm{f} . \text { d. } Q}\right)-$ factor of the form of active (reactive) load diagram;

$K_{\text {c.d. } P}\left(K_{\text {c.d. } Q}\right)$ - factor of the completion of active (reactive) load diagram;

$P_{R M C P}\left(P_{R M C Q}\right)-$ RMS power of active (reactive) load.

I-II The array of generation parameters is a matrix similar to MP, but the columns of the matrix characterize the initial parameters of units

$$
R G=\left[\begin{array}{ccc}
P_{R G 1} & \ldots & P_{R G n} \\
Q_{R G 1} & \ldots & Q_{R G n} \\
S_{R G 1} & \ldots & S_{R G n} \\
\cos \varphi_{R G 1} & \ldots & \cos \varphi_{R G n}
\end{array}\right] .
$$

Thus, RG matrix is a complete basis of units considered in the task. When considering several manufacturers or types of units, it is possible to divide the base into subarrays, which does not preclude the integration at subsequent stages for the convenience of solving global and local tasks.

Stage II - Determination of the maximum power of a power unit. The main task of this action is to set the limits of choice that determine the minimum and maximum power of the unit. The minimum power is the lower limit of produced power, the power of a single unit. The maximum power determines the fulfillment of requirements for the necessary and sufficient provision of the object's calculated load. The determination of the maximum capacities of the power unit depends on the purpose of optimization and the planned profile of power supply operation: parallel or isolated work; full or partial compensation of external consumption. For tasks with full compensation, the minimum level of produced power is determined by the minimum values of load diagram

$$
P_{\Sigma D G \min }=\frac{P_{M P \min }}{f_{c}}
$$

where $P_{M P \min }$ - the minimum power value chosen from the $\mathbf{M P}_{\max }$ array; 
$f_{c} \approx 0,7 \div 0,8-$ corrective factor that is conditionally a stock factor and is taken in accordance with the maximum value of the efficiency for a single unit.

To ensure consumer assumed loads, necessary and sufficient limits of the power unit are determined by the following system:

$$
\left\{\begin{array}{l}
P_{\Sigma D G \max } \geq \frac{P_{M P \max }}{f_{c}} \\
P_{\Sigma D G \max } \leq \frac{P_{M P \max }}{f_{c} f_{s}}
\end{array},\right.
$$

where $P_{M P \max }$ - the maximum power value, selected from the $\mathbf{M P}_{\max }$ array;

$f_{s}$ - stock factor adopted in accordance with the values given in [4], taking into account the number of aggregates available by the requirements of technological reserve.

It is practically impossible to form consumers load diagram unchanged in time. At the same time, due to coordinated use of external power sources and DG means, it is possible to achieve a certain increase in the uniformity of load diagrams generated in power networks. In this case, the degree of uniformity will be characterized by the form factor of the corresponding load diagram. Theoretically, it is possible to implement such a policy by applying differentiated tariffs for electricity, for example, in the same way as the payment for the consumed reactive power for consumers, involved in its regulation together with the power system, is formed.

For tasks with incomplete compensation (aimed at cutting the maximum loads during parallel operation with the power system), the limits, determined by the shape of load diagram, are imposed

$$
\begin{gathered}
P_{\Sigma D G \text { min }}=\frac{P_{M P \min }}{f_{c} \cdot K_{\mathrm{f} . \mathrm{d} . P}}, \\
P_{\Sigma D G \max }=\frac{P_{M P \max }}{f_{c} \cdot K_{\mathrm{f} . \mathrm{d} . P}},
\end{gathered}
$$

where $P_{M P \text { min }}$ - the minimum power value, selected from the $\mathbf{M P}_{\min }$ array;

$K_{\text {f.d.P }}-$ form factor of the consumer load diagram.

Stage III - Direct selection - optimization. At the stage of direct selection, structural optimization is carried out. The target function (TF) $f$, which is formed under the basic mathematical apparatus of the task, is mathematical representation of the optimal criterion. As a rule $[5 ; 6]$, both technical and economic indices serve as the basis for the TF synthesis. The criteria for payback and the assessment of the effectiveness of investment in DG objects construction are the most popular economic indices. Another way to determine the best value of the solution is to calculate technical characteristics as defining criteria: the minimum of electricity losses, increased reliability of power supply and indicators of electricity quality. But this is most often dictated by the need to solve a particular task.

On the basis of dependencies, characterizing the influence of parameters and the structure of electrotechnical complexes with distributed energy sources on the parameters of the operating mode of distribution network, the target function of optimization of these parameters and structure can be presented.
As the first criterion, the minimum of active power losses in the ETC in the mode of the maximum load $\left(P_{\text {loss. max load }}\right)$, which is the function of active $\left(P_{D G}\right)$ and reactive $\left(Q_{D G}\right)$ power of the generator, as well as the place of its installation $\left(\lambda_{D G}\right)$, is taken:

$$
f_{1}=P_{\text {loss. max load }}\left(P_{D G}, Q_{D G}, \lambda_{D G}\right) \text {. }
$$

As the second criterion, the minimum of active power losses in the ETC in the mode of the minimum load $\left(P_{\text {loss min load }}\right)$, which is also a function of active and reactive power of the generator and the place of its installation, is taken:

$$
f_{2}=P_{\text {loss. min load }}\left(P_{D G}, Q_{D G}, \lambda_{D G}\right) \text {. }
$$

The main limiting condition at the optimization of operating mode of distribution network of an industrial enterprise consists in the requirements regarding the values of the continued permissible current in ij line

$$
I_{i j} \leq I_{i j \max }
$$

where $I_{i j}$ - operating value of the current in $i j$ line, $I_{i j \max }$ - continued allowable current in $i j$ line.

In addition, the voltage in $i$ node should be within the range of $\left[0,9 \cdot U_{\text {nom }} ; 1,1 \cdot U_{\text {nom }}\right]$ :

$$
0,9 \cdot U_{\text {nот }} \leq U_{i} \leq 1,1 \cdot U_{\text {nom }},
$$

where $U_{i}$-operating value of the voltage of $i$ node, $U_{\text {nom }}-$ nominal voltage of distribution network.

Obviously, the lower limit in this case also represents a set of Pareto-optimal solutions.

To determine the optimal structure of electrotechnical complex with local energy sources, it is assumed to apply the target function obtained by the scalarization method:

$$
\begin{gathered}
F=\beta_{1} f_{1}+\beta_{2} f_{2}, \\
\text { where } \beta_{1}=\frac{t_{P_{\max }}+t_{Q_{\max }}}{\left(t_{P_{\max }}+t_{Q_{\max }}\right)+\left(t_{P_{\min }}+t_{Q_{\min }}\right)} \text {-weight fac- }
\end{gathered}
$$

tor at the function of the minimum of active power losses in hours of the maximum load;

$$
\beta_{2}=\frac{t_{P_{\min }}+t_{Q_{\min }}}{\left(t_{P_{\max }}+t_{Q_{\max }}\right)+\left(t_{P_{\min }}+t_{Q_{\min }}\right)}-\text { weight factor at }
$$

the function of the minimum of active power losses in hours of the minimum load;

$t_{P_{\max }}-$ the duration of the maximum load of active power;

$t_{Q_{\max }}$ - the duration of the maximum load of reactive power;

$t_{P_{\min }}$ - the duration of the minimum load of active power;

$t_{Q_{\min }}$ - the duration of the minimum load of reactive power.

The application of restrictions to function (12) significantly reduces the dimension of the set of permissible values and, as a consequence, of solutions. In this case, the target function has the minimum value that corresponds to the optimal generator power.

Thus, in order to determine the optimal parameters of electrotechnical complex in the structure of PSS and DG, it is expedient to use the minimum of function (12) as an efficiency index, taking into account the constraints (10) and (11).

As a result of the analysis of these dependencies, the target function of the task of optimizing the operation of distribution network of an industrial enterprise containing local energy source, as well as the constraints, is formulated. 
As a numerical method for finalizing, a direct comparison of options with economic indices of discounted payback period or net discounted income is possible. Henceforth, we have used the proposed in [7] estimate of the project effectiveness by defining the integral level of competitiveness (ILC)

$$
\begin{gathered}
I T L_{j} \cdot c_{1}+T C O_{j} \cdot c_{2}+D P P_{j} \cdot c_{3}+N P V_{j} \cdot c_{4}+ \\
+I R R_{j} \cdot c_{5}+D P I_{j} \cdot c_{6}=I L C_{j},
\end{gathered}
$$

where $c_{1}, c_{2}, c_{3}, c_{4}, c_{5}, c_{6}$ - coefficients of insignificance;

$$
\begin{aligned}
& I T L_{j} \text { - integral technical level; } \\
& T C O_{j} \text { - total cost of ownership; } \\
& D P P_{j}-\text { discounted payback period; } \\
& N P V_{j} \text { - net discounted income; }
\end{aligned}
$$

$I R R_{j}$ - internal rate of return;

$D P I_{j}$ - discounted profitability index.

Conclusions. The technique of parametric optimization of ETC with DG, which lies in the definition of physically substantiated characteristics of power units and consists of three stages: formation of initial data; determination of the maximum power of a power unit; direct selection (optimization), is developed.

The formation of initial parametric base, as well as the use of flexible criteria for options selection allows the dynamic adjustment of the task and application both for the design of objects under construction, and for the modernization of existing systems.

\section{References:}

1. Pregelj A., Begovic M., Rohatgi A. (2006). Reclosers allocation for improved reliability of DG-enhanced distribution networks. IEEE Transactions on Power Systems, vol. 21, no. 3, pp. 1442-1449.

2. Lezhniuk P.D., Rubanenko O.Ye., Malohulko Yu.V. (2014). Optimization of the operation of dispersed energy sources in local electrical systems. Visnyk NTU "KhPI», no. 60 (1102). (in Ukrainian)

3. Samoilyk O.V., Kurbaka H.V., Dudnyk M.V. (2016, November). Analysis of power balance of local power supply system on the basis of renewable energy sources and storage batteries. Energosberezheniye. Energetika. Energoaudit, no. 11(154), pp. 22-32. (in Ukrainian)

4. Kharitonov D.A. (2007). Development of the technique for the selection and rational use of cogeneration systems as a source of electric power at the enterprise according to technical and economic criteria: thesis dor a Doctor's degree in Engineering. GOU VPO "Moscow Energy Institute (Technical University)". (in Russian)

5. Guk Yu.B., Sinenko M.M., Tremyasov V.A. (1990). Calculation of reliability of power supply circuits. Leningrad: Energoatomizdat, Leningr. otdeleniye. (in Russian)

6. Georgilakis P.S., Hatziargyrios N.D. (2013, August). Optimal distributed generation placement in power distributed network: models, methods, and future research. IEEE Trans. Power Syst, vol. 28, no. 3.

7. Aleksakhina L.I., Kurochkin D.S., Mikheev D.V. (2013). The structure of the technical and economic substantiation of innovative projects in the field of energy efficiency of industrial enterprises. Transport Business in Russia, no. 6, pp. 202-205. (in Russian) 